\title{
Morphological and morphometric evaluation of prepubertal gilt ovaries, uterine tubes and uterus at different oestrus cycle stages $^{1}$
}

\author{
Guilherme Oberlender², Thais P. Pontelo ${ }^{3}$, José R. Miranda4, David R. Miranda4, \\ Márcio G. Zangeronimo ${ }^{3 *}$, Adriana C. Silva ${ }^{3}$, Tila A. Menezes ${ }^{3}$ and Luiz G.P. Rocha ${ }^{3}$
}

\begin{abstract}
Oberlender G., Pontelo T.P., Miranda J.R., Miranda D.R., Zangeronimo M.G., Silva A.C., Menezes T.A. \& Rocha L.G.P. 2014. Morphological and morphometric evaluation of prepubertal gilt ovaries, uterine tubes and uterus at different oestrus cycle stages. Pesquisa Veterinária Brasileira 34(1):83-90. Setor de Fisiologia e Farmacologia Veterinárias, Departamento de Medicina Veterinária, Universidade Federal de Lavras, Campus Universitário s/n, Caixa Postal 3037, Lavras, MG 37200-000, Brazil. E-mail: zangeronimo@dmv.ufa.br
\end{abstract}

Studies are performed in developing techniques/procedures that provide greater reproductive performance in farm animals, including pigs. In this sense, the study of gilts reproductive organs at different oestrus cycle stages for assessing the presence of abnormalities and/or other parameters that may affect the future animal fertility is important. In order to evaluate the morphological, morphometric and histomorphometric features of ovaries, uterus and uterine tubes (UTs) characteristics of prepubertal gilts at different oestrus cycle stages, reproductive tracts from 48 animals immediately after slaughter were obtained. After, the structures were dissected and removed, and the ovaries were used for classification of oestrus cycle stage of each gilt in follicular phase (FP) and luteal phase (FL). Then, morphometric evaluations of ovaries, UTs, uterine horns and uterine body were performed. Besides that, medial segments of UTs and uterus were fixed in Bouin solution, processed and included in paraffin, when histological sections of 5.0 micrometers $(\mu \mathrm{m})$ were obtained and stained with Hematoxylin and Eosin. Histomorphometric analyzes using image capture system and specific software were performed. Afterwards, data were submitted to Student's $\mathrm{t}$ test for assessment the statistical differences $(\mathrm{P}<0.05)$ between the two different oestrus cycle stages $(\mathrm{FP} \times \mathrm{LP})$ and between the placement of reproductive structures (right $\times$ left antimer). Among the gilts evaluated, 35 were in the FP and 13 in LP. There was no difference $(\mathrm{P}>0.05)$ between morphometric parameters of ovaries, UTs and uterus of gilts in FP and LP. Likewise, in respect to the placement of reproductive structures, both in the oestrus cycle stages, as in the general average, there was no difference $(\mathrm{P}>0.05)$. Regarding the histomorphometric variables, gilts classified in FP presented a higher $(\mathrm{P}<0.05)$ height of glandular and UT epithelium compared to animals in LP. On the other hand, the diameter of endometrial glands was higher $(\mathrm{P}<0.05)$ in gilts at $\mathrm{LP}$ compared to FP. Furthermore, gilts in LP presented a higher $(\mathrm{P}<0.05)$ proportion of endometrium occupied by glands, whereas animals in FP had a higher $(\mathrm{P}<0.05)$ proportion of connective tissue and blood vessels. In conclusion, in prepubertal gilts, the histomorphometric parameters as endometrial glands diameter, the height of glandular epithelium and of UT epithelium and the proportion of

\footnotetext{
${ }^{1}$ Received on February 7, 2013.

Accepted for publication on January 9, 2014.

${ }^{2}$ Curso de Medicina Veterinária, Universidade Federal da Fronteira Sul (UFFS), Campus Realeza. Acesso Rodovia PR-182 Km 466, Rua Edmundo Gaievski, 1000, Bairro Jardim Primavera, Cx. Postal 253, Realeza, PR 85770-000, Brazil. E-mail: guilherme.oberlender@uffs.edu.br
} 
endometrium occupied by connective tissue, besides the glands and blood vessels varies through the oestrus cycle, possibly under the influence of ovarian steroids.

INDEX TERMS: Follicular phase, histology, luteal phase, morphology, morphometry, reproduction, reproductive tract, swine.

RESUMO.- [Avaliação morfológica e morfométrica de
ovários, tubas uterinas e útero de fêmeas suínas pré-pú-
beres em diferentes fases do ciclo estral.] Pesquisas são realizadas no desenvolvimento de técnicas/procedimentos que propiciem maior eficiência reprodutiva em animais de produção, dentre esses, os suínos. Nesse sentido, o estudo dos órgãos reprodutivos das fêmeas suínas em diferentes fases do ciclo estral é importante para avaliação da presença de anomalias e/ou demais parâmetros que possam afetar a fertilidade futura do animal. Objetivando-se avaliar as características morfológicas, morfométricas e histomorfométricas dos ovários, útero e tubas uterinas (TUs) de fêmeas suínas pré-púberes em diferentes fases do ciclo estral, tratos reprodutivos foram obtidos de 48 animais imediatamente após o abate. Posteriormente, as estruturas foram dissecadas e retiradas, sendo os ovários utilizados para a classificação da fase do ciclo estral de cada fêmea em fase folicular (FF) e fase luteínica (FL). Em seguida, foram realizadas avaliações morfométricas dos ovários, TUs, cornos uterinos e corpo uterino. Após, segmentos mediais das TUs e útero foram fixados em solução de Bouin, processados e incluídos rotineiramente em parafina, quando cortes histológicos de 5,0 micrômetros $(\mu \mathrm{m})$ foram obtidos e corados com Hematoxilina e Eosina. Análises histomorfométricas foram realizadas utilizando sistema de captura de imagens e software específico. Posteriormente, os dados obtidos foram submetidos ao teste t de Student para a avaliação de diferenças estatísticas $(\mathrm{P}<0,05)$ entre as diferentes fases do ciclo estral (FF $\times$ FL) e entre a localização das estruturas reprodutivas (antímero direito $\times$ esquerdo). Dentre as fêmeas avaliadas, 35 encontravam-se na FF e 13 na FL. Não houve diferença $(P>0,05)$ entre os parâmetros morfométricos dos ovários, TUs e útero das fêmeas nas FF e FL. Da mesma forma, em relação à localização das estruturas reprodutivas, tanto nas duas fases do ciclo estral, como na média geral, não houve diferença $(\mathrm{P}>0,05)$. Em relação às variáveis histomorfométricas, as fêmeas classificadas na FF apresentaram maior $(\mathrm{P}<0,05)$ altura do epitélio glandular e da TU em comparação com os animais na FL. Por outro lado, o diâmetro das glândulas endometriais foi maior $(P<0,05)$ nas fêmeas classificadas na FL em comparação com a FF. Além disso, as fêmeas na FL apresentaram maior $(\mathrm{P}<0,05)$ proporção do endométrio ocupada por glândulas, enquanto que as fêmeas da FF apresentaram maior $(\mathrm{P}<0,05)$ proporção de tecido conjuntivo e vasos sanguíneos. Em conclusão, em fêmeas suínas pré-púberes, os parâmetros histomorfométricos, o diâmetro das glândulas endometriais, a altura do epitélio glandular e da TU e a proporção do endométrio ocupada por tecido conjuntivo, além das glândulas e vasos sanguíneos variam ao longo do ciclo estral, possivelmente devido à influência dos esteróides ovarianos.

TERMOS DE INDEXAÇÃO: Aparelho reprodutor, fase folicular, fase luteínica, histologia, morfologia, morfometria, reprodução, suíno.

\section{INTRODUCTION}

In animal production, when studying the female reproductive tract, one of the most important aspects is the herd reproductive performance, and this is a technical approach with profit purpose, which is the main objective of pig farming (Monteiro \& Carvalho 2006). This fact is important, once fertility disorders may lead to the gilts culling resulting in lose of productivity (Heinonen et al. 1998).

In pig farming, the artificial insemination is a widespread technique used to reduce production costs and to achieve a better use of the male gametes into porcine (Severo et al. 2011). Furthermore, in order to achieve high productivity indices (weaned piglets), the gilts should be prepared for insemination and thus, making an efficient use of the pregnancy and parturition installations, and also being prepared to replace the slaughtered sows (Stančić et al. 2012). However, this situation does not always happens in practice.

Approximately 30 to $40 \%$ of gilts does not show signs of oestrus, even after 8 months of age, and, these animals are slaughtered, on their majority, before the first insemination as gilts that present delayed puberty, namely, gilts in prolonged anestrus pre-insemination (Stančić et al. 2008, Gagrčin et al. 2009). In addition, among 13 to $49 \%$ of swine females removal is related to reproductive failure (López-Serrano et al. 2000, Diehl et al. 2003). Given this, one of the current challenges in pig production systems is maintain constant the level of gilts productivity.

Some of the main components of the female reproductive tract are uterus and uterine tubes (UTs), essential organs for reproduction, and its growth is regulated by several factors (Spencer et al. 2005). These structures undergo by a large number of variations according to the animal's age and to the occurrence of pregnancies (Monteiro et al. 2003, Guimarães et al. 2004). In pigs, studies have been performed analyzing the behavior of uterus and endometrium related to the fertility (Johnson et al. 2009, Bazer et al. 2012). Regarding the UTs, few studies have been done (Guimarães et al. 2004, Tienthai et al. 2006), although it is essential at transport and interaction between gametes, at maintenance of sperm and oocytes viable until the fertilization and spermatic capacitation (Rodriguez-Martinez et al. 2001, Coy et al. 2008).

Besides the aforementioned organs, the ovaries also are part of the female reproductive tract. These are in pairs, with varied placement and size between animal species and are responsible for the production of gametes and hormones (Hafez \& Hafez 2004, Câmara \& Cunha Dias 2008). The assessment of morphological characteristics of the ovaries may be used to investigate the presence of pathologies such as cysts and tumors, and may also be useful in order to estimate which is the probable oestrus cycle stage and, this way, can affect the future fertility of the animal (Nascimento et al. 2003, Ramos et al. 2008). 
Studies of the morphological, morphometrics and histomorphometrics characteristics of the reproductive organs of nulliparous females in different oestrus cycle stages are important as a tool for assessing the reproductive status of these animals before the first insemination and pregnancy, considering that gilts are the replacement animals and that they often present reproductive disorders, which increases the production costs.

Considering the above, this study aimed to evaluate the morphological, morphometrics and histomorphometrics characteristics of the ovaries, uterus and UTs of prepubertal gilts in different oestrus cycle stages.

\section{MATERIALS AND METHODS}

\section{Ethics}

The present study was conducted after the institutional approval of the Federal University of Lavras (UFLA), with all experimental protocols being compliant with the Ethical Principles of Animal Experiments adopted by the Institutional Animal Care and Use Committee Guidelines of this institution, under the protocol number 009/10.

\section{Place of investigation and location of animals}

The study was performed at the laboratories of Veterinary Physiology and Pharmacology and Veterinary Morphology, located at the Department of Veterinary Medicine (DVM) at UFLA. All biological material was obtained from a slaughterhouse ("Matadouro/Frigorífico NUTRILI") situated in Lavras city, Minas Gerais state, Brazil, during the months of May to October 2012. A total of 48 Landrace $\times$ Large White prepubertal gilts (lineage cross-bred commercial - Genetics AGROCERES) aged 5 to 6 months and weighing between 90 to $100 \mathrm{~kg}$ on average were used.

\section{Oestrus cycle classification}

For each slaughtered female, the reproductive tract was collected and the oestrus cycle stage were classified in follicular phase (FP) or luteal phase (LP), according to the methodology described by Hafez \& Hafez (2004). The FP was characterized by the presence of growing ovarian follicles $(2-5 \mathrm{~mm}$ in diameter) or preovulatory follicles $(8-11 \mathrm{~mm}$ in diameter) or almost ovulating (greater than $11 \mathrm{~mm}$ in diameter). In this phase it can also be observed the presence of corpus luteum in regression process and without vascularization on the surface, and/or the presence of albicans bodies from previous cycles. On the other hand, LP was characterized by the presence of recent hemorrhagic bodies or much vascularized corpus luteum in the periphery or in the ovarian stigma. In this phase are also observed small growing follicles (smaller than $2.0 \mathrm{~mm}$ in diameter) and the presence or absence of corpus luteum.

\section{Ovaries, uterus and uterine tubes collection and preparation}

After slaughter and animals evisceration, the female genitalia, including ovaries, UTs, uterus, cervix, vagina, vulva and urinary bladder were collected, identified and individually stored in polystyrene box with ice (Tummaruk et al. 2009). Subsequently it was transported to the laboratory of Physiology and Pharmacology (DVM/UFLA) within a period of one hour.

In order to obtain the ovaries, uterus and UTs of each female, the reproductive tract was dissected and these structures were removed using scissors. Subsequently were adequately identified and stored in $0.9 \%$ (w:v) NaCl solution at $37^{\circ} \mathrm{C}$ until the morphological and morphometric analyzes were performed.

\section{Morphological and morphometric evaluation}

For morphological and morphometric evaluation of the ovaries, it were removed and identified in right ovary (RO) and left ovary (LO). After, they were measured at larger (major axis) and lower length (axis between ovarian pedicle and the opposite extremity) using a caliper (graduated in millimeters - mm), respecting the organ symmetry (Nascimento et al. 2003, Câmara \& Cunha Dias 2008, Ramos et al. 2008). For the assessment of the weight (grams), in each gilt the RO and LO was individually weighted using electronic digital analytical balance (capacity $=220 \mathrm{~g}$, accuracy of $0.01 \mathrm{~g}$, AY-220, Shimadzu, Japan).

The UTs and uterine horns were dissected of the mesosalpinx and mesometrium, isolated and the length of the right and left antimer of each structure measured (Tummaruk et al. 2009). For UTs, the length was estimated from the UT abdominal ostium to the uterine ostium of the UT. For uterine horns, the measurement was initiated of the light of each horn, from the uterine body, to the beginning of each UT (Santos et al. 2000). As to the ovary, the UTs and uterine horns were individually weighted.

\section{Histological preparation}

Afterwards the classification of the oestrus cycle stage and the morphological and morphometric evaluations, the histological preparation of biological materials obtained was performed. The slides preparation was performed at the laboratory of Veterinary Morphology (DVM/UFLA) from the samples of horns and UTs of each animal previously obtained.

For histological evaluation, fragments of approximately $2.0 \mathrm{~cm}$ in length of the medial portion of both uterine horns, right and left, and segments of approximately $0.5 \mathrm{~cm}$ of the right and left ampulla UTs region were collected. Following, the material obtained was fixed in Bouin solution (75\% saturated picric acid solution, $25 \%$ formaldehyde and 5\% glacial acetic acid) for a period of 24 hours (Eigenheer-Moreira et al. 2007, Moraes et al. 2007, Aleixo et al. 2011). Then, the samples were dehydrated with increasing concentrations of ethanol, cleared in xylene and included in paraffin (Drummond et al. 2004). Afterwards, transverse cross-sections of $5.0 \mu \mathrm{m}$ in thick (Monteiro \& Carvalho 2006, Monteiro et al. 2006) were obtained, mounted on microscope slides and stained with Hematoxylin and Eosin for subsequent histomorphometric analysis (Oberlender et al. 2012b).

\section{Morphometric evaluation}

Histomorphometric analyzes were performed from photomicroscopy obtained by the system of image's capture consisting in trinocular microscope (CX31, Olympus Optical do Brasil Ltda, São Paulo, São Paulo), camera of digital image capture (SC30, Olympus Optical do Brasil Ltda, São Paulo, SP), Cell ${ }^{\mathrm{B}}$ software (Imaging Software for Life Science Microscopy, Olympus Optical do Brasil Ltda, São Paulo, SP) and $4 \times$ lens and 10× magnification eyepieces was used. After, the obtained images were analyzed with the ImageJ software (NIH, Research Services Branch, National Institute of Mental Health, Bethesda, Maryland, United State of America).

In accordance with Tienthai et al. (2006), microscopic evaluation of horns and UTs samples were performed by a single researcher (T.P. Pontelo), who had no knowledge about animals identification, in other words, all the slides were coded before the analysis.

The evaluations performed on each slide were: total thickness $(\mu \mathrm{m})$ of the uterine wall (analysis of five different fields in each histological sample); total thickness of the endometrium $(\mu \mathrm{m})$ (five different fields in each histological sample); diameter of the normal endometrial glands and the dilated ones, when present (20 different fields for each histological sample); height of the endometrial glandular epithelium and UT epithelial height (20 different fields for each histological sample). With the use of graticule 
containing 352 points was also evaluated the proportion of endometrium occupied by endometrial glands, blood vessels, connective tissue and epithelium. For this purpose were evaluated 15 fields per animal, totalizing 5,280 points.

\section{Experimental design}

For the assessment of morphological, morphometric and histomorphometric characteristics of nulliparous gilts ovaries, uterus and UTs at different oestrus cycle stages, a simple model of analysis to compare the mean of two different treatments (Oberlender et al. 2012a) (oestrus cycle stage $-\mathrm{FP} \times \mathrm{LP}$ and the placement of reproductive structures - right $\times$ left antimer) in the reproductive tracts obtained were used.

\section{Statistical analysis}

Data are presented as mean \pm standard deviation (SD). For each analyzed variable (weight of the uterine horns, uterus, uterine tubes and ovaries; length of the uterus body, uterine horns, uterine tubes, larger and smaller length of the ovaries, total thickness of the uterus and endometrium, endometrial glands diameter, height of the glandular and uterine tube epithelium and proportion of endometrium occupied by epithelium, connective tissue glands and blood vessels), data were submitted to normality analysis (Kolmogorov-Smirnov test) and test of the variances homoscedasticity (Levene). Afterwards, data were submitted to Student's t test to assess the statistical differences between the two different oestrus cycle stages $(\mathrm{FP} \times \mathrm{LP})$ and between the placement of reproductive structures (right $\times$ left antimer). A significance level of $5 \%$ was considered to indicate a statistical difference. All statistical analyses were performed using the statistical package SPSS for Windows version 17.0 .

\section{RESULTS}

From a total of animals evaluated, 35 (72.92\%) were in the FP and 13 gilts (27.08\%) in LP of oestrus cycle.

There was no difference $(P>0.05)$ for the weight and length of the different organs of the gilts reproductive tract evaluated in this study, classified in the FP and LP of oestrus cycle (Table 1). Likewise, regarding the placement of reproductive structures, namely, between the right and left antimer, the weight and length of ovaries, UTs and uterine horns of the gilts, in average and in both oestrus cycle stages not showed difference $(\mathrm{P}>0.05)$ (Table 2, Fig.1).

There were difference $(\mathrm{P}<0.05)$ for the histomorphometric variables diameter of the endometrial glands, height of glandular epithelium and height of UT epithelium between gilts classified in the FP and LP of the oestrus cycle (Table $3)$. The gilts classified in FP of the oestrus cycle presented a higher $(\mathrm{P}<0.05)$ height of glandular and UT epithelium compared with animals in LP. On the other hand, the diameter of endometrial glands was higher $(\mathrm{P}<0.05)$ in gilts at LP compared with FP of oestrus cycle (Fig.2). Regarding the histomorphometric analysis, total thickness of the uterus and endometrium, and proportion of endometrium occupied by epithelium, no differences $(\mathrm{P}>0.05)$ were observed between the animals in FP and LP.

For the proportion of endometrium occupied by endometrial tissue, glands and blood vessels, there were difference $(\mathrm{P}<0.05)$ between the animals classified in both

\footnotetext{
${ }^{5}$ SPSS Statistics 17.0, Rel. 17.0.1. 2008, SPSS Inc, Chicago, IL.
}

Table 1. Weight and morphometric data (mean \pm SD) of reproductive organs of prepubertal gilts in follicular and luteal stage of oestrus cycle ( $n=48$ animals)

\begin{tabular}{|c|c|c|c|c|c|}
\hline $\begin{array}{l}\text { Analyzed } \\
\text { variable }\end{array}$ & $\begin{array}{l}\text { Oestrus cycle } \\
\text { stage }\end{array}$ & Mean \pm SD & Minimum & Maximum & $P$ value \\
\hline Weight of the & Follicular & $36.93 \pm 17.44$ & 15.11 & 76.25 & 0.203 \\
\hline & Lut & & & & \\
\hline horn (grams) & Mean & $37.45 \pm 15.49$ & 15.11 & 76.25 & \\
\hline Weight of the & Follicular & $37.00 \pm 17.08$ & 15.70 & 72.94 & 0.357 \\
\hline left uterine & Luteal & $40.83 \pm 9.28$ & 34.84 & 51.52 & \\
\hline horn (grams) & Mean & $37.82 \pm 15.50$ & 15.70 & 72.94 & \\
\hline Total weight & Follicular & $62.70 \pm 32.71$ & 27.86 & 167.52 & 0.170 \\
\hline of the uterus & Luteal & $54.28 \pm 19.15$ & 28.98 & 97.47 & \\
\hline (grams) & Mean & $60.42 \pm 29.70$ & 27.86 & 167.52 & \\
\hline Weight of the & Follicular & $1.01 \pm 0.31$ & 0.59 & 1.62 & 0.555 \\
\hline right uterine & Luteal & & & 1.59 & \\
\hline $\mathrm{ms)}$ & Mean & & & 1.62 & \\
\hline Weight of the & Follicular & & & & 0.851 \\
\hline left uterine & Luteal & & & 7 & \\
\hline Jrams) & Mean & & & & \\
\hline Weight of the & Follicular & 3.72 & 0.7 & 48 & 0.400 \\
\hline ry & Luteal & 4.1 & & 8 & \\
\hline (gra & Mea & & 0.78 & 8 & \\
\hline Weight of the & Follicular & 3 & 4 & 7 & 0.683 \\
\hline left ovary & Luteal & 8 & 1.93 & 9.35 & \\
\hline tz & $\mathrm{Me}$ & 8 & .93 & 9.35 & \\
\hline of & Follicular & $4.17 \pm$ & 0 & 6.50 & 0.179 \\
\hline & & $5.77 \pm$ & & 5.80 & \\
\hline body & Mean & $4.36 \pm$ & 3.00 & 6.50 & \\
\hline Length of the & Follicular & $49.75 \pm 12.64$ & 32.50 & 96.50 & 0.336 \\
\hline & Luteal & $45.71 \pm 8.95$ & 30.00 & 61.50 & \\
\hline horn $(\mathrm{cm})$ & Mean & 48.66 & 30 & & \\
\hline Length of the & Follicular & 11.00 & 35.00 & 86.50 & 0.240 \\
\hline left uterine & Luteal & $48.12 \pm 7.68$ & 37.00 & 61.40 & \\
\hline horn $(\mathrm{cm})$ & Mean & $50.12 \pm 10.20$ & 35.00 & 86.50 & \\
\hline Length of the & Follicular & $18.35 \pm 2.35$ & 15.20 & 22.00 & 0.052 \\
\hline right uterine & Luteal & $20.07 \pm 4.65$ & 14.70 & 23.00 & \\
\hline tube $(\mathrm{cm})$ & Mean & & 14.70 & 23.00 & \\
\hline Length of the & Follicular & $20.27 \pm 3.18$ & 16.50 & 26.80 & 0.947 \\
\hline left uterine & Luteal & $20.87 \pm 3.63$ & 17.00 & 24.20 & \\
\hline & Mean & $20.40 \pm 3.14$ & 16.50 & 26.80 & \\
\hline Larger length & Follicular & $2.71 \pm 0.32$ & 100 & 3.50 & 0.150 \\
\hline & Luteal & & & 20 & \\
\hline & Mean & & 1.90 & 3.90 & \\
\hline Smaller length & h Follicular & $1.81 \pm 0.27$ & 1.20 & 2.20 & 0.198 \\
\hline & Luteal & & & 2.30 & \\
\hline ovary (cm) & Mean & & 1.20 & 2.30 & \\
\hline Larger length & Follicular & $2.75 \pm 0.33$ & 2.00 & 3.40 & 0.446 \\
\hline & & & 2.1 & - & \\
\hline & & & 2.00 & 3.50 & \\
\hline Smaller length & h Follicular & $1.92 \pm 0.23$ & 1.40 & 2.50 & 0.669 \\
\hline & & & 1.40 & 2.70 & \\
\hline ovary $(\mathrm{cm})$ & Mean & $1.92 \pm 0.25$ & 1.40 & 2.70 & \\
\hline
\end{tabular}

phases of the oestrus cycle (Table 4). Gilts in LP presented a higher $(\mathrm{P}<0.05)$ proportion of endometrium occupied by glands, whereas animals in FP presented a higher $(\mathrm{P}<0.05)$ proportion of connective tissue and blood vessels (Fig.2).

\section{DISCUSSION}

This study described the morphology, morphometry and histomorphometry of the ovaries, uterus and UTs of prepubertal gilts in FP and LP of the oestrus cycle. We demonstrated that weight and morphometry of prepubertal gilts reproductive organs does not differ in its placement (right and left antimer) and between the FP and LP of oestrus cycle. 
Table 2. Weight and morphometric data (mean \pm SD) of reproductive organs of prepubertal gilts in follicular and luteal stage of oestrus cycle in comparison with its placement (right and left antimer) $(n=48$ animals)

\begin{tabular}{|c|c|c|c|c|c|c|}
\hline $\begin{array}{l}\text { Analyzed } \\
\text { variable }\end{array}$ & $\begin{array}{c}\text { Oestrus f } \\
\text { cycle } \\
\text { stage }\end{array}$ & Placement & t Mean \pm SD & Minimum & Maximum & $\begin{array}{c}P \\
\text { value }\end{array}$ \\
\hline \multirow{6}{*}{$\begin{array}{l}\text { Weight of the } \\
\text { uterine horn } \\
\text { (grams) }\end{array}$} & \multirow[t]{2}{*}{ Follicular } & Left & $37.00 \pm 17.08$ & 15.70 & 72.94 & \multirow[t]{2}{*}{0.993} \\
\hline & & Right & $36.93 \pm 17.44$ & 15.11 & 76.25 & \\
\hline & \multirow[t]{2}{*}{ Luteal } & Left & $40.83 \pm 9.28$ & 34.84 & 51.52 & \multirow[t]{2}{*}{0.275} \\
\hline & & Right & $39.36 \pm 5.75$ & 35.39 & 45.95 & \\
\hline & \multirow[t]{2}{*}{ Mean } & Left & $37.82 \pm 15.50$ & 15.70 & 72.94 & \multirow[t]{2}{*}{0.877} \\
\hline & & Right & $37.45 \pm 15.49$ & 15.11 & 76.25 & \\
\hline \multirow{6}{*}{$\begin{array}{l}\text { Weight of the } \\
\text { uterine tube } \\
\text { (grams) }\end{array}$} & \multirow[t]{2}{*}{ Follicular } & Left & $1.05 \pm 0.33$ & 0.65 & 1.73 & \multirow[t]{2}{*}{0.716} \\
\hline & & Right & $1.01 \pm 0.31$ & 0.59 & 1.62 & \\
\hline & \multirow[t]{2}{*}{ Luteal } & Left & $1.13 \pm 0.35$ & 0.76 & 1.47 & \multirow[t]{2}{*}{0.712} \\
\hline & & Right & $1.22 \pm 0.42$ & 0.76 & 1.59 & \\
\hline & \multirow[t]{2}{*}{ Mean } & Left & $1.07 \pm$ & 0.65 & 1.73 & \multirow[t]{2}{*}{0.983} \\
\hline & & Right & 1.05 & 0.59 & 1.62 & \\
\hline \multirow{6}{*}{$\begin{array}{l}\text { Weight of the } \\
\text { ovary (grams) }\end{array}$} & \multirow[t]{2}{*}{ Follicular } & Left & $4.32 \pm 1.23$ & 2.64 & 7.87 & \multirow[t]{2}{*}{0.980} \\
\hline & & Right & $3.72 \pm 1.36$ & 0.78 & 7.48 & \\
\hline & \multirow[t]{2}{*}{ Luteal } & Left & $4.14 \pm$ & 1.93 & 9.35 & \multirow[t]{2}{*}{0.763} \\
\hline & & $\mathrm{Ri}$ & & & 9.38 & \\
\hline & \multirow[t]{2}{*}{ Mean } & & 4.2 & & 9.35 & \multirow[t]{2}{*}{0.778} \\
\hline & & Right & 3.8 & 0 & 8 & \\
\hline \multirow{6}{*}{$\begin{array}{l}\text { Length of the } \\
\text { uterine horn } \\
(\mathrm{cm})\end{array}$} & \multirow[t]{2}{*}{ Follicular } & Left & 50.86 & 35.00 & 86.50 & \multirow[t]{2}{*}{0.696} \\
\hline & & Right & 2.64 & 32.50 & 96.50 & \\
\hline & Luteal & Left & $48.12 \pm 7.68$ & 37.00 & 61.40 & 0.734 \\
\hline & & Right & 3.95 & 30.00 & 61.50 & \\
\hline & Mean & Left & $50.12 \pm 10.20$ & 35.00 & 86.50 & 0.675 \\
\hline & & Right & 48.6 & 30.0 & 96.50 & \\
\hline Length of the & Follicular & Left & $20.27 \pm 3.18$ & 16.50 & 26.80 & 0.461 \\
\hline & & Right & 18.35 & 15.20 & 22.00 & \\
\hline & Luteal & Left & $20.87 \pm 3.63$ & 17.00 & 24.20 & 0.507 \\
\hline & & Right & $20.07 \pm 4.65$ & 14.70 & 23.00 & \\
\hline & Mean & Left & $20.40 \pm 3.14$ & 16.50 & 26.80 & 0.898 \\
\hline & & Right & $18.71 \pm 2.85$ & 14.70 & 23.00 & \\
\hline Larger length & Follicular & Left & $2.75 \pm 0.33$ & 2.00 & 3.40 & 0.961 \\
\hline of the ovary & & Right & $2.71 \pm 0.32$ & 1.90 & 3.50 & \\
\hline$(\mathrm{cm})$ & Luteal & Left & $2.68 \pm 0.39$ & 2.10 & 3.50 & 0.592 \\
\hline & & Right & $2.72 \pm 0.47$ & 2.10 & 3.90 & \\
\hline & Mean & Left & $2.73 \pm 0.35$ & 2.00 & 3.50 & 0.782 \\
\hline & & Right & $2.72 \pm 0.37$ & 1.90 & 3.90 & \\
\hline Smaller length & Follicular & Left & $1.92 \pm 0.23$ & 1.40 & 2.50 & 0.291 \\
\hline of the ovary & & Right & $1.81 \pm 0.27$ & 1.20 & 2.20 & \\
\hline$(\mathrm{cm})$ & Luteal & Left & $1.94 \pm 0.30$ & 1.40 & 2.70 & 0.493 \\
\hline & & Right & $1.87 \pm 0.25$ & 1.20 & 2.30 & \\
\hline & Mean & Left & $1.92 \pm 0.25$ & 1.40 & 2.70 & 0.588 \\
\hline & & Right & $1.83 \pm 0.26$ & 1.20 & 2.30 & \\
\hline
\end{tabular}

We also reported that prepubertal gilts during FP of oestrus cycle presented a higher epithelial and UTs glandular epithelium height, and higher proportion of endometrium occupied by connective tissue and blood vessels. On the other hand, in the LP of oestrus cycle, gilts presented a higher diameter of endometrial glands and a higher proportion of endometrium occupied by glands.

\section{Morphological and morphometric evaluation}

The morphology of ovaries obtained showed, mostly, characteristic of prepubertal animals. In other words, ovaries without the presence of albicans body and corpus luteum or ovulation signals (Bagg et al. 2004, Knox 2005) (Fig.1). This finding can be confirmed by the greater number of gilts classified in the follicular (72.92\%) than luteal (27.08\%) stage of the oestrus cycle. According to Hafez \&
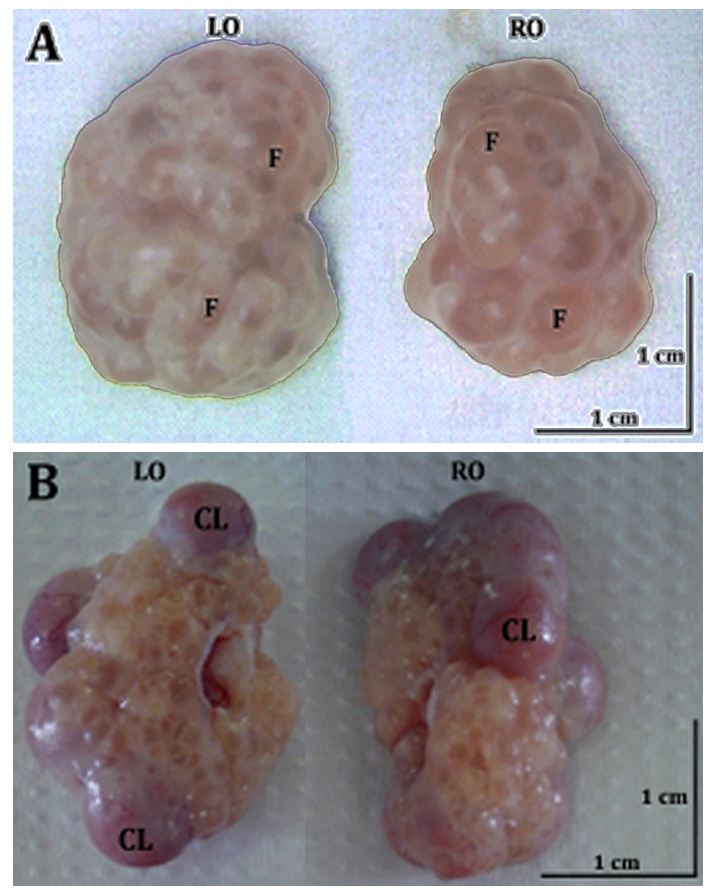

Fig.1. Ovaries of prepubertal gilts (A) in follicular and (B) in luteal stage of oestrus cycle. $\mathrm{LO}=$ left ovary, $\mathrm{RO}=$ right ovary, $\mathrm{F}=$ follicle and $\mathrm{CL}=$ corpus luteum. Note the high population of ovarian follicles in Figure A and the high population of CL in Figure B.

Table 3. Morphometric parameters (mean \pm SD) of reproductive organs of prepubertal gilts in follicular and luteal stage of oestrus cycle ( $n=48$ animals)

\begin{tabular}{lccccc}
\hline $\begin{array}{l}\text { Analyzed } \\
\text { variables }\end{array}$ & $\begin{array}{c}\text { Oestrus } \\
\text { cycle stage }\end{array}$ & Mean \pm SD & Minimum & Maximum P value \\
\hline Total thickness & Follicular & $2183.39 \pm 574.87$ & 1359.49 & 3722.56 & 0.205 \\
of the uterus & Luteal & $1847.82 \pm 352.33$ & 1149.35 & 2417.77 & \\
$(\mu \mathrm{m})$ & Mean & $2067.67 \pm 527.92$ & 1149.35 & 3722.56 & \\
Total thickness of & Follicular & $1393.62 \pm 385.85$ & 921.76 & 2238.71 & 0.221 \\
the endometrium & Luteal & $1160.18 \pm 213.72$ & 914.32 & 1551.28 & \\
$(\mu \mathrm{m})$ & Mean & $1313.12 \pm 350.92$ & 914.32 & 2238.71 & \\
Endometrial & Follicular & $10.07 \pm 3.82^{\mathrm{b}}$ & 5.26 & 19.04 & $0.049^{*}$ \\
glands diameter & Luteal & $13.00 \pm 10.41^{\text {a }}$ & 3.63 & 39.87 & \\
$(\mu \mathrm{m})$ & Mean & $11.08 \pm 6.80$ & 3.63 & 39.87 & \\
Height of the & Follicular & $16.32 \pm 2.29^{\text {a }}$ & 12.98 & 21.79 & $0.016^{*}$ \\
glandular & Luteal & $15.16 \pm 1.01^{\text {b }}$ & 13.20 & 16.93 & \\
epithelium $(\mu \mathrm{m})$ & Mean & $15.92 \pm 2.00$ & 12.98 & 21.79 & \\
Height of the & Follicular & $24.77 \pm 2.17^{\text {a }}$ & 16.37 & 28.89 & $0.034^{*}$ \\
uterine tube & Luteal & $18.33 \pm 2.27^{\mathrm{b}}$ & 14.73 & 20.49 & \\
epithelium $(\mu \mathrm{m})$ & Mean & $18.57 \pm 2.16$ & 14.73 & 28.89 &
\end{tabular}

*Means followed by different letters in the column differ by Student's $\mathrm{t}$ test $(\mathrm{P}<0.05)$.

Hafez (2004), the FP of oestrus cycle in porcine females is characterized by the presence of ovaries with follicles in growth stage and up to nearly ovulating.

Jiménez Loaiza et al. (2012) studying the relation of physiological status of ovaries with the causes of porcine females discard at different ages, reported, differently of what were obtained in the present study, that most of females discarded presented in LP (53.1\%) in comparison with FP (34.2\%) of oestrus cycle. On the other hand, as 

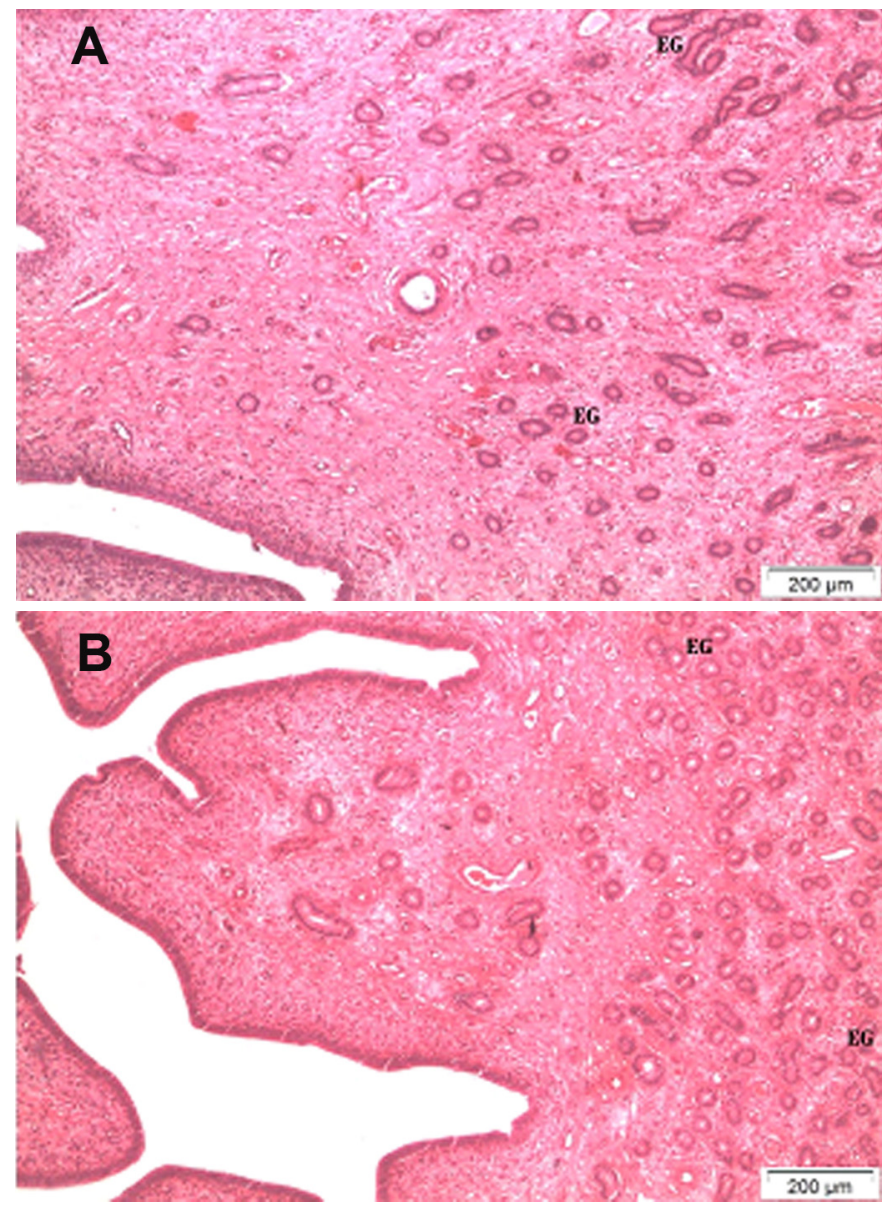

Fig.2. Histological section $(40 x)$ of prepubertal gilts uterine endometrium (A) in follicular and (B) in luteal stage of oestrus cycle. $\mathrm{EG}=$ endometrial glands. Note the higher proportion of endometrium occupied by endometrial glands in gilts at luteal phase of oestrus cycle in Figure B.

Table 4. Proportion of uterine endometrium occupied by different structures in prepubertal gilts in follicular and luteal stage of oestrus cycle ( $n=48$ animals)

\begin{tabular}{|c|c|c|c|c|c|}
\hline $\begin{array}{l}\text { Components of the } \\
\text { endometrium }\end{array}$ & $\begin{array}{l}\text { e } \text { Oestrus } \\
\text { cycle stage }\end{array}$ & Mean \pm SD & Minimum & Maximum & P value \\
\hline \multirow{3}{*}{ Epithelium } & Follicular & $4.60 \pm 1.18$ & 3.09 & 6.90 & \multirow{3}{*}{0.457} \\
\hline & Luteal & $4.16 \pm 1.02$ & 2.95 & 5.87 & \\
\hline & Mean & $4.46 \pm 1.13$ & 2.95 & 6.90 & \\
\hline \multirow{3}{*}{$\begin{array}{l}\text { Connective } \\
\text { tissue }\end{array}$} & Follicular & $65.64 \pm 8.55^{a}$ & 48.31 & 78.11 & \multirow[t]{3}{*}{$0.038^{*}$} \\
\hline & Luteal & $60.85 \pm 6.89^{b}$ & 51.96 & 71.92 & \\
\hline & Mean & $64.10 \pm 8.25$ & 48.31 & 78.11 & \\
\hline \multirow[t]{3}{*}{ Glands } & Follicular & $23.64 \pm 9.24^{b}$ & 5.18 & 41.52 & \multirow[t]{3}{*}{$0.035^{*}$} \\
\hline & Luteal & $29.95 \pm 7.14^{a}$ & 20.13 & 39.15 & \\
\hline & Mean & $25.67 \pm 9.00$ & 5.18 & 41.52 & \\
\hline \multirow[t]{3}{*}{ Blood vessels } & Follicular & $6.12 \pm 2.88{ }^{a}$ & 2.99 & 13.06 & \multirow[t]{3}{*}{$0.047^{*}$} \\
\hline & Luteal & $5.04 \pm 2.97^{b}$ & 3.10 & 11.95 & \\
\hline & Mean & $5.77 \pm 2.89$ & 2.99 & 13.06 & \\
\hline
\end{tabular}

*Means followed by different letters in the column differ by Student's $t$ test $(\mathrm{P}<0.05)$.

observed by Diehl et al. (2003), Moreira et al. (2006) and Karvelienë \& Riðkevièienë (2009), all gilts evaluated in our study presented active ovaries, so because, the FP and LP of oestrus cycle represent normal cyclicity conditions of ovaries.
Regarding the weight and morphometry of reproductive organs, the obtained values for ovaries weight in both stages of oestrus cycle and in both antimers (right and left) resemble those described by Cowan \& MacPherson (1966), Schwarze \& Schröder (1970) and McEntee (1990), that demonstrated in their studies ovarian weights ranging from 1.30 to $12.20 \mathrm{~g}$, 8.00 to $14.00 \mathrm{~g}$ and 7.00 to $20.00 \mathrm{~g}$ respectively. Guimarães et al. (2004) reported average weights of the RO and LO of $4.40 \pm 2.56 \mathrm{~g}$ and $4.70 \pm 7.20 \mathrm{~g}$, respectively, and these values were also similar to averages obtained in the present study. The results of ovarian morphometry, regardless of oestrus cycle stage and antimer, were similar to those obtained by Bagg et al. (2004), who found an average of $2.41 \mathrm{~cm}$ for the greatest length and $1.59 \mathrm{~cm}$ for the smallest ovary length from prepubertal gilts of the same breed used in this study.

Regarding the length of UTs, Schwarze \& Schröder (1970) demonstrated that these structures measure between 15.00 and $30.00 \mathrm{~cm}$ in porcine females. Thus, regardless of oestrus cycle stage and antimer, the values obtained in the present study are within the physiological range for the specie. The values obtained in our study were similar to those reported by Cowan \& MacPherson (1966) that described values of $16.90 \pm 2.98 \mathrm{~cm}$ and $17.73 \pm 3.69 \mathrm{~cm}$ for the length of right and left UT respectively. In this work, as observed in our study, the length of UT in the left antimer was numerically greater than the right antimer.

Guimarães et al. (2004) working with Landrace gilts, reported values of $45.90 \pm 6.80 \mathrm{~cm}$ and $35.60 \pm 4.29 \mathrm{~cm}$ for the right and left UT length respectively. The data obtained by these authors were higher than those obtained in our study, regardless of the oestrus cycle stage, and this fact may be due to lower number of animals used in this study (five), so the findings can be justified by the individual variability of animals. Also, a possible explanation would be that the gilts used, even being nulliparous, could already have reached the puberty, in contrast to the animals used in the present study that were all prepubertal. According with this explanation, Cowan \& MacPherson (1966) described that the length of UTs increases with the advancing of reproductive status.

For the length of uterine horns, regardless of oestrus cycle stage and antimer, the values obtained in our study are in accordance with those described for pigs which are of 39.80-150.00cm (Cowan \& MacPherson 1966). The results obtained in the present study differ from those obtained by Guimarães, Machado \& Santos (2004) which reported values of $77.20 \pm 17.35 \mathrm{~cm}$ and $90.00 \pm 18.09 \mathrm{~cm}$ for right and left length of uterine horn, respectively. On the other hand, our results resemble those obtained by Cowan \& MacPherson (1966) that observed values of $50.11 \pm 10.11 \mathrm{~cm}$ and $50.20 \pm 10.44 \mathrm{~cm}$ for right and left uterine horns, respectively. In this work as well as observed in our study for UTs, the length of uterine horn in left antimer was numerically higher than right antimer.

Talking about the length of uterine body, the average obtained in our study, in FP and LP of the oestrus cycle, was similar to demonstrated by Guimarães et al. (2004) $(4.50 \pm 0.28 \mathrm{~cm})$, but higher than the average reported by Cowan \& MacPherson (1966) $(2.22 \pm 0.83 \mathrm{~cm})$ in prepubertal gilts. 


\section{Histomorphometric evaluation}

The endometrial glands are tubular structures delineated by simple columnar epithelium (Monteiro \& Carvalho 2006) and are presented sinuous and branched. It opens inwards the endometrium surface, except in the caruncular areas (in ruminants). According Hafez \& Hafez (2004), during the oestrus, endometrial glands are presented relatively straight and once the increase of progesterone level produced by the corpus luteum under development, its grow up, secrete and become more sinuous and complex. The glands begin to regress when the first signs of uterine regression are also observed.

Thus, the larger diameter of endometrial glands in the gilts classified in FP compared to LP may be explained by the following reason: the LP of oestrus cycle is characterized by a higher concentration of progesterone and this is secreted by the luteal cells of corpus luteum, placenta and adrenal gland (Hafez \& Hafez 2004). Furthermore, progesterone prepares the endometrium for implantation and pregnancy maintenance by increasing the secretory glands in endometrium and also by the inhibition of myometrium motility (Carvalho et al. 2003). According Mayor et al. (2004), uterine endometrium is thicker in pregnant females in comparison with non-pregnant, and this is due to the morphology of endometrial glands, which varies according the reproductive stage and undergo hyperplasia during pregnancy and LP of oestrus cycle.

The FP of oestrus cycle in porcine is characterized by high estrogen concentrations, and this acts in the uterus inducing an increase in the mass of endometrium and myometrium (Hafez \& Hafez 2004, Bertan et al. 2006). Thus, this fact can explain the higher height of endometrial glandular epithelium in gilts classified in FP of oestrus cycle compared with LP.

According to Bertan et al. (2006), during FP of oestrus cycle, estrogen induce cell proliferation in endometrium, while in LP, higher concentrations of progesterone inhibits the mitosis of endometrial tissue. Progesterone induces endometrial stroma differentiation, stimulates glandular secretion in association with accumulation of basal vacuoles in glandular epithelium and promotes the proteins release by endometrial cells, which will help the beginning of embryo development.

Regarding the height of UT epithelium, the results observed in the present study are similar to those reported by Steinbach \& Smidt (1970) and Sant'Ana et al. (2003), that observed higher epithelial height for gilts classified in FP $(28.90 \pm 5.00 \mu \mathrm{m} v s 22.07 \pm 3.84 \mu \mathrm{m})$ in comparison with LP $(22.70 \pm 1.80 \mu \mathrm{m} v s 18.41 \pm 3.12 \mu \mathrm{m})$ of oestrus cycle, respectively. This fact coincides with the higher metabolic activity and the higher morphophysiological complexity of this segment, since the fertilization and early embryo development occur in this portion of UT (Abe 1996). On the other hand, Bal \& Getty (1970) observed changes in morphology of gilts UT related with age advancing, but without no influence in respect to the oestrus cycle stages. Sant'Ana et al. (2004) demonstrated that the height of gilts UTs is greater in ampulla region followed by infundibulum and isthmus. In contrast, Steinbach \& Smidt (1970) described no changes in epithelial height per segment of UTs.
The results of UTs epithelial height, between oestrus cycle stages, obtained in the present study are in accordance with Mayor et al. (2004), which reported that there are cyclical changes in ciliated and secretory cells of UTs epithelium, and in gilts in FP, the ciliary cells predominate, whereas in non-pregnant females in LP and in pregnant the secretory cells become more apparent that the ciliary epithelium. Furthermore, these events suffer the influence of ovarian hormones. The estrogen stimulates the growth of ciliated epithelium and the synthesis of granules in secretory cells, whereas the progesterone antagonizes the growth of these cells. Therefore, this fact justifies the higher epithelial height of UTs in gilts classified in FP of oestrus cycle.

The larger proportion of endometrium occupied by connective tissue and blood vessels in gilts classified in FP of oestrus cycle compared with LP (Fig.2) can be explained due to the higher concentrations of estrogen and this, as previously described, is responsible for inducing an increase in the mass of endometrium and uterine myometrium (Hafez \& Hafez 2004, Bertan et al. 2006).

\section{CONCLUSIONS}

This study described the morphology, morphometry and histomorphometry of the ovaries, uterus and UTs of prepubertal gilts in FP and LP of the oestrus cycle.

The endometrial glands diameter, height of glandular epithelium and of UT epithelium and the proportion of endometrium occupied by connective tissue, glands and blood vessels varies through the oestrus cycle in porcine, possibly under the influence of ovarian steroids.

The weight and morphometry of prepubertal gilts ovaries, uterus and UTs are similar in its placement (right and left antimer) and between the FP and LP of oestrus cycle.

Acknowledgements.- To the staff of the slaughterhouse "Matadouro/Frigorífico NUTRILI", Lavras/MG for supplying the biological samples. This work was supported in part by FAPEMIG (the Research Support Foundation of the State of Minas Gerais), CNPq (the National Council for Scientific and Technological Development), CAPES (Coordination of Improvement of Higher Education Personnel), the Veterinary Science Graduate Programme and the Graduate Directory of the Federal University of Lavras, Brazil.

\section{REFERENCES}

Abe H. 1996. The mammalian oviductal epithelium: regional variations in cytological and functional aspects of the oviductal secretory cells. Histol. Histopathol. 11:743-768.

Aleixo V.M., Pressinoti L.N., Campos D.V.S., Menezes-Aleixo R.C. \& Ferraz R.H.S. 2011. Histologia, histoquímica e histometria do intestino de jacaré-do-Pantanal criado em cativeiro. Pesq. Vet. Bras. 31:1120-1128.

Bagg M.A., Vassena R., Papasso-Brambilla E., Grupen C.G., Armstrong D.T. \& Gandolfi F. 2004. Changes in ovarian, follicular, and oocyte morphology immediately after the onset of puberty are not accompanied by an increase in oocyte developmental competence in the pig. Theriogenology 62:1003-1011.

Bal H.S. \& Getty R. 1970. Changing morphology of the uterine tubes of the domestic pig (Sus scrofa domesticus) with age. J. Gerontol. 25:347-353.

Bazer F.W., Song G., Kim J., Dunlap K.A., Satterfield M.C., Johnson G.A., Burghardt R.C. \& Wu G. 2012. Uterine biology in pigs and sheep. J. Anim. Sci. Biotechnol. 3:1-21.

Bertan C.M., Binelli M., Madureira E.H. \& Traldi A.S. 2006. Mecanismos endócrinos e moleculares envolvidos na formação do corpo lúteo e na luteólise - revisão de literatura. Braz. J. Vet. Res. Anim. Sci. 43:824-840. 
Câmara A. \& Cunha Dias R.V. 2008. Características morfométricas de ovários de fêmeas bovinas SRD, colhidos no abatedouro público municipal de Umarizal/RN. Acta Vet. Bras. 2:89-92.

Carvalho L.F.R., Silva Filho J.M., Silva I.J., Bandeira M.N., Morais M.P. \& Ruas J.R.M. 2003. Efeito da aplicação de hCG ou GnRH sobre a concentração sérica de progesterona e eficiência reprodutiva em porcas. Arq. Bras. Med. Vet. Zootec. 55:659-664.

Cowan F.T. \& MacPherson J.W. 1966. The reproductive tract of the porcine female: a biometrical study. Can. J. Comp. Med. Vet. Sci. 30:107-108.

Coy P., Cánovas S., Mondéjar I., Saavedra M.D., Romar R., Grullón L., Matás C. \& Avilés M. 2008. Oviduct-specific glycoprotein and heparin modulate sperm-zona pellucida interaction during fertilization and contribute to the control of polyspermy. Proc. Natl Acad. Sci. U.S.A. 105:15809-15814.

Diehl G.N., Costi G., Vargas A.J., Richter J.B., Lecznieski L.F., Bortolozzo F.P., Bernardi M.L. \& Wentz I. 2003. Monitoramento ovariano ao abate de leitoas descartadas por anestro ou estro atípico. Arch.Vet. Sci. 8:121-125.

Drummond C.D., Murgas L.D.S., Bertechini A.G., Rodenas C.E.O., Maciel M.P., Alvarenga A.L.N. \& Sousa S.Z. 2004. Índice e histologia gonadal em reprodutores de frangos de corte da linhagem Avian Farm submetidos à restrição alimentar. Ciênc. Agrotec. 28:1408-1414.

Eigenheer-Moreira J.F., Fernandes F.T., Queiroz F.J.R., Pinho T.G. \& Ferreira A.M.R. 2007. Estudo comparativo de éguas repetidoras ou não de cio através da avaliação histológica do endométrio e das concentrações plasmáticas de progesterona. Pesq. Vet. Bras. 27:506-512.

Gagrčin M., Stančić I., Božić A., Stančić B., Harvey R. \& Anderson R. 2009. Reproductive performance of gilts in a big farm in Vojvodina. Vet. Glasnik 63:77-86.

Guimarães G.C., Machado M.R.F. \& Santos A.L.Q. 2004. Variáveis morfológicas dos órgãos genitais femininos de suínos da raca Landrace (Sus scrofa domesticus Linnaeus, 1758). Biosci. J. 20:131-136.

Hafez B. \& Hafez E.S.E. 2004. Anatomia da reprodução feminina, p.13-39. In: Hafez B. \& Hafez E.S.E. (Eds), Reprodução Animal. 7ạ Ed. Manole Ltda, São Paulo.

Heinonen M., Leppävuori A. \& Pyörälä S. 1998. Evaluation of reproductive failure of female pigs based on slaughterhouse material and herd record survey. Anim. Reprod. Sci. 52:235-244.

Jiménez Loaiza E.M., Mateus Vargas R.H., Alfaro Zúñiga C.E. \& Passos Pequeno A. 2012. Relación del estado fisiológico de ovarios de cerdas con la causa del descarte en dos granjas de Costa Rica. Revta Cient. 22:341-347.

Johnson G.A., Bazer F.W., Burghardt R.C., Spencer T.E., Wu G. \& Bayless K.J. 2009. Conceptus-uterus interactions in pigs: endometrial gene expression in response to estrogens and interferons from conceptuses. Soc. Reprod. Fertil. Suppl. 66:321-332.

Karvelienë B. \& Riðkevièienë V. 2009. Post-mortem evaluation of genital organs from sows with reproductive disturbances. Vet. Arhiv. 79:269279.

Knox R.V. 2005. Recruitment and selection of ovarian follicles for determination of ovulation rate in the pig. Domest. Anim. Endocrinol. 29:385397.

López-Serrano M., Reinsch N., Looft H. \& Kalm E. 2000. Genetic correlations of growth, backfat thickness and exterior with stayability in large white and landrace sows. Livest. Prod. Sci. 64:121-131.

Mayor P., Jori F. \& López-Béjar M. 2004. Anatomicohistological characteristics of the tubular genital organs of the female collared peccary (Tayassu tajacu) from North-eastern Amazon. Anat. Histol. Embryol. 33:65-74.

McEntee K. 1990. Reproductive Pathology of Domestic Mammals. Academic Press, San Diego. 401p.

Monteiro C.M.R., Farias E.C., Perri S.H.V. \& Souza W.M. 2003. Estudo das características histológicas do útero e tubas uterinas de vacas e novilhas da raça Nelore (Bos primigenius indicus). Braz. J. Vet. Res. Anim. Sci. 40:45-54.

Monteiro C.M.R. \& Carvalho R.G. 2006. Caracterização histológica do útero, tubas uterinas e ovários de fêmeas recém-nascidas, pré-púberes e púberes de suínos mestiços (Sus scrofa domestica Linnaeus, 1758). Ars Vet. 22:223-228.

Monteiro C.M.R., Koivisto M.B. \& Silva A.M. 2006. Perfil histológico do útero e ovários de gatas submetidas à ovariosalpingohisterectomia. Ars Vet. 22:236-241.

Moraes C., Baraldi-Artoni S.M., Oliveira D., Pacheco M.R., Amoroso L. \& Franzo V.S. 2007. Morfologia e morfometria do oviduto de codornas Nothura maculosa. Ciência Rural 37:146-152.

Moreira F., Pilati C., Reis R., Dick W. \& Sobestiansky J. 2006. Aspectos macroscópicos dos ovários de matrizes suínas, oriundas de granjas da microrregião de Rio Verde-Go e descartadas para abate por motivos diversos. Arch. Vet. Sci. 11:47-52.

Nascimento A.A., Pinheiro N.L., Sales A. \& Viana J.H.M. 2003. Correlação morfométrica do ovário de fêmeas bovinas em diferentes estádios reprodutivos. Braz. J. Vet. Res. Anim. Sci. 40:126-132.

Oberlender G., Murgas L.D.S., Zangeronimo M.G., Silva A.C., Pereira L.J. \& Muzzi R.A.L. 2012a. Comparison of two different methods for evaluating boar semen morphology. Arch. Med. Vet. 44:201-205.

Oberlender G., Murgas L.D.S., Zangeronimo M.G., Wouters F., Silva A.C., Mesquita L.P., Bezerra Júnior P.S. \& Pereira L.J. 2012b. Testicular hypoplasia in boar: association between seminal analysis and histopathology. Revta Cient. Eletr. Med. Vet. 10:1-17.

Ramos E.M., Cavalcante T.V., Nunes R.R.M., Oliveira C.M., Silva S.M.M.S., Dias F.E.F, Maruo V.M. \& Arrivabene M. 2008. Morfometria ovariana de vacas zebuínas criadas na Amazônia Oriental. Revta Bras. Saúde Prod. Anim. 9:696-702.

Rodriguez-Martinez H., Tienthai P., Suzuki K., Funahashi H., Ekwall H. \& Johannisson A. 2001. Involvement of oviduct in sperm capacitation and oocyte development in pigs. Reprod. 58(Suppl.):129-145.

Sant'ana F.J.F., Nascimento E.F., Nogueira J.C. \& Serakides R. 2003. Altura do epitélio da tuba uterina normal e patológica de porcas nas fases folicular e luteínica. Arq. Bras. Med. Vet. Zootec. 55:226-229.

Sant'ana F.J.F., Nascimento E.F., Nogueira J.C. \& Serakides R. 2004. Atividade secretória de tubas uterinas com e sem patologia de porcas adultas nas fases folicular e luteínica. Arq. Bras. Med. Vet. Zootec. 56:36-45.

Santos T.C., Miglino M.A., Machado G.V. \& Souza W.M. 2000. Morfologia dos ovários, tubas uterinas e útero em catetos (Tayassu tajacu, Linnaeus, 1758) e queixadas (Tayassu pecari Link, 1795). Braz. J. Vet. Res. Anim. Sci. 37:1-12.

Schwarze E. \& Schröder L. 1970. Sistema visceral, p.195-202. In: Schwarze E. \& Schröder L. (Eds), Compendio de Anatomia Veterinária. Tomo II. Acribia, Zaragoza.

Severo C.K., Pereira G.R., Pereira A.M., Ilha G.F., Oliveira J.F.C., Soares M., Arruda R.P. \& Gonçalves P.B.D. 2011. Cysteine addition on short-term cooled boar semen preservation and its relationship with swine field fertility. Pesq. Vet. Bras. 31:25-32.

Spencer T.E., Hayashi K., Hu J. \& Carpenter K.D. 2005. Comparative developmental biology of the mammalian uterus. Curr. Top. Dev. Biol. 68:85-122.

Stančić I., Gagrčin M., Anderson R., Harvey R., Stančić B., Radović I. \& Božić A. 2008. Prolonged preinsemination anestrus in gilts. Contemporary Agriculture 57:97-105.

Stančić I.B., Bošnjak D.V., Radović I.B., Stančić B.L., Harvey R.B. \& Anderson R.C. 2012. Ovarian reaction and estrus manifestation in delayed puberty gilts after treatment with equine chorionic gonadotropin. Reprod. Biol. Endocrinol. 10:1-5.

Steinbach J. \& Smidt D. 1970. Cyclical phenomena in the female genital tract of swine: histological observations. J. Anim. Sci. 30:573-577.

Tienthai P., Sajjarengpong K. \& Tummaruk P. 2006. Morphological changes in the oviduct of culling replacement gilts. Thai J. Vet. Med. 36:41-54.

Tummaruk P., Kesdangsakonwut S. \& Kunavongkrit A. 2009. Relationships among specific reasons for culling, reproductive data, and gross morphology of the genital tracts in gilts culled due to reproductive failure in Thailand. Theriogenology 71:369-375. 